\title{
FORMS OF COERCION IN PEACEFUL CHRISTIAN MISSIONS
}

\author{
Marius Ščavinskas
}

\begin{abstract}
The article analyses forms of coercion employed in so-called peaceful Christian missions. Two forms of coercion are distinguished: social, implemented by the ruler towards his subjects, and political, imposed by a conqueror. However, the fact that on certain occasions missionaries employed both social and political forms of coercion is also taken into consideration. These occasions were cases when missionaries who faced a polarised nobility lacking a strong political leader (the nobility and/or the ruler would be the backbone of a successful mission) would undertake the formation of political structures, thus absorbing secular functions as well. This happened to the first bishops who worked among the Prussians and Livonians (Christian, Meinhard, Berthold and Albert). On the other hand, the analysis revealed that peaceful missions, as they have been perceived in historiography, contained certain forms of coercion defined by the term 'social coercion'. Thus the logical question arises: what kind of missions can be qualified as military/coercive which in historiography are most frequently named 'Schwertmission'? The article suggests the conclusion that, in their nature, Schwertmission were different from the so-called 'sword missions', yet were loaded with social coercion. Hence, Schwertmission and Crusade are not identical concepts, though they are still used as such in historiography. ${ }^{1}$
\end{abstract}

In the early 1930s, the German historian H. Achterberg, who analysed the spread of Christian missions in the Germanic (and other) tribes, suggested that Christian missions should be grouped on the basis of their work methods: Wortmission (verbal missions), Tatmission (action missions) and Schwertmission (sword missions). ${ }^{2}$ Undoubtedly, the latter method has received the biggest share of scholars' attention. Worth mentioning is the research performed by

${ }^{1}$ This research was funded by the Research Council of Lithuania within the framework of the Postdoctoral Fellowship Implementation in Lithuania project.

${ }^{2}$ H. Achterberg, Interpretatio Christiana. Verkleidete Glaubensgestalten der Germanen auf deutschem Boden (Leipzig, 1930), p. 87. 
H.D. Kahl and H. Dörries, ${ }^{3}$ German specialists in medieval history, which had a significant influence on later generations of scholars. 4 This also applies to the Christianisation that followed the conquest of the Baltic and Finno-Ugric tribes. ${ }^{5}$

In fact, speaking about the missions to the lands of the Balts and Livonians, certain reservations are frequently employed: the activities of bishops Meinhard and Christian are most often characterised as peaceful, whereas those of bishops Berthold and Albert are presented as military/coercive. ${ }^{6}$ Besides, historiography still deals with the question whether the Teutonic Order pursued Christian missions or not. ${ }^{7}$ C.T. Maier, who attempted to explore the inconsistencies,

${ }^{3}$ H.D. Kahl, “'Compellere intrare”. Die Wendenpolitik Bruns von Querfurt im Lichte hochmittelterlichen Misions - und Wölkerrechts', Zeitschrift für Ostforschung, 4 (1955), pp. 363-86; H. Dörries, 'Fragen der Schwertmission', Baltische Kirchengeschichte. Beiträge zur Geschichte der Missionierung und Reformation, der evangelisch-lutherischen Landeskirchen und des Volkskirchentums in den baltischen Landen, ed. R. Wittram (Göttingen, 1956), pp. 17-25.

${ }^{4}$ Cf. H. Boockmann, Der Deutsche Orden. Zwölf Kapitel aus seiner Geschichte (Munich, 1981); Cf. M. Hardt, 'Some Remarks on the Christianisation of the Saxons', Castri Dominae Nostrae Litterae Annales, Vol. I: Christianization of the Baltic Region, ed. J. Gąssowski (Pułtusk, 2004), pp. 94-100; L.E. Padberg, Die Christianisierung Europas im Mittelalter (Stuttgart, 1998); F. Lotter, 'The Crusading Idea and the Conquest of the Region East of the Elbe', Medieval Frontier Societies, ed. R. Bartlett, A. MacKay (Oxford, 1989), pp. 267-73.

${ }^{5}$ For more information, see P. Rebane, 'Denmark, the Papacy and the Christianization of Estonia', Gli inizi del Cristianesimo in Livonia-Lettonia (Rome, 1989), pp. 182-201; T. Lindkvist, 'Crusades and Crusading Ideology in the Political History of Sweden 1140-1500', Crusade and Conversion on the Baltic Frontier 1150-1500, ed. A.V. Murray (Aldershot-Burlington, 2001), pp. 1202. J. Møller Jensen, 'Denmark and the Holy War: a Redefinition of a Traditional Pattern of Conflict 1147-1169', Scandinavia and Europe 800-1350. Contact, Conflict and Coexistence, ed. J. Adams, K. Holman (Turnhout, 2004), pp. 220-32.

${ }^{6}$ Sources and debates related to the issue are presented at length in the study conveying the contradictory approaches of two scholars: C.S. Jensen, 'The Early Stage of Christianisation in Livonia in Modern Historical Writings and Contemporary Chronicles', Studia Fennica. Historica 9: Medieval History Writing and Crusading Ideology, ed. T.M.S. Lehtonen, K.V. Jansen, J. Malkki, K. Ritari (Helsinki, 2005), pp. 207-15; M. Dygo, 'Mission und Kreuzzug in der Anfängen der Christianisierung Livlands', Kryžiaus karu epocha Baltijos regiono tautu istorinejje sqmonejje, ed. R. Trimonienè, R. Jurgaitis, (Šiauliai, 2007), pp. 66-84.

${ }^{7}$ For latest estimations, see I. Fonnesberg-Schmidt, The Popes and the Baltic Crusades 1147-1254, p. 61; B. Bombi, 'Innocent III and the Praedicatio to the Heathens in Livonia (1198-1204)', Medieval History Writing and Crusading Ideology, pp. 233-8. 
revealed that the missionaries could crusade and preach the Gospel at the same time, paying little attention to the inconsistency. ${ }^{8}$ Finally, it is noteworthy that, as R. Wenskus correctly remarked in his study in 1956, the groups of people that were targets of coercive missions should also be differentiated. ${ }^{9}$ However, this idea was not fully developed in historiography. Some historians suggested that the term for coercive missions (Schwertmission) should be abandoned, as coevals did not know this concept, yet this approach received rigid criticism from other scholars. ${ }^{10}$ Thus, 'sword evangelisation' is still perceived as a matter-of-course and there is little need to question it. ${ }^{11}$

On the other hand, historians who practically equated the military/ coercive missions to the Crusades, in the majority of cases perceived the conquest policy of the Teutonic Order as a specific occurrence in the Crusades ${ }^{12}$ or Litauerreisen. ${ }^{13}$ The abovementioned estimations make the issue of military/coercive missions more complicated, but more interesting as well.

Looking through the historiography of many decades, one cannot help but notice two interesting aspects which have received little consideration from researchers so far. The grouping of missions into peaceful and military can hardly account for the reasons and time of the introduction of elements of coercion into the missions. This is a

${ }^{8}$ C.T. Maier, Preaching the Crusades. Mendicant Friars and the Cross in the Thirteenth Century (Cambridge, 2006), pp. 48-52.

${ }^{9}$ R. Wenskus, Studien zur Historisch-Politischen Gedankenwelt Bruns von Querfurt (Münster-Cologne, 1956), pp. 149-52.

${ }^{10}$ Cf. S. Ekdahl, 'Die Rolle der Ritterorden bei der Christianisierung der Liven und Letten', Gli inizi del Cristianesimo, pp. 205-6.

${ }^{11}$ Contemporary German historians come up with yet another term Einkirchung which refers to a certain 'involvement into church', enforcement of certain norms of Christian life (through evangelisation) on the converts who had to accept them without any questions. The German historian Horst Fuhrmann gives an example of the said enforcement ('christianae religioni subiungere'), for more information, see H. Fuhrmann, Deutsche Geschichte im hohen Mittelalter (Göttingen, 2003), pp. 147-8. Similarly, the concept Einkirchung was perceived by Michael Borgolte who practically equated it to indirekten Misionskrieg, see M. Borgolte, Die mittelalterliche Kirche (Munich, 2004), p. 11.

12 J.A. Brundage, 'The Thirteenth-Century Livonian Crusade: Henricus de Lemtis and the First Legatine Mission of Bishop William of Modena', of the same, The Crusades, Holy War and Canon Law (Hampshire, 1991), pp. 1-9.

${ }^{13}$ A. Ehlers, 'Crusade of the Teutonic Knights against Lithuania Reconsidered' Crusade and Conversion, pp. 25-42. 
surprising question, especially bearing in mind the encouragement by the Holy See to undertake peaceful Christian missions at the time when the Crusades were in progress in the Baltic region. ${ }^{14}$ Moreover, it is not exactly clear what kind of coercion should be discussed, especially considering separate specific cases. It is scarcely correct to group the missions into peaceful and military, with reference to the fact that the missionary was either preceded or followed by troops. It is more than obvious that it was the secular government (speaking in modern concepts, as it was not until the papacy of Pope Gregory VII that laymen were distinguished from the whole of christianitas) rather than the missionary who had the authority to employ certain coercive methods, which in historiography are still perceived as Schwertmission. The missionary, however, could also exercise certain coercive methods with the help of military (and other) forces. This is the first aspect. The second arises from attempts to explain the transition from peaceful missions to military/ coercive ones. The briefly discussed historiography suggests that we take into consideration the factor of the Crusades, and proposes the abovementioned hybrid term Missionskrieg. ${ }^{15}$ Not discounting the factor of the Crusades, in my opinion this development of the evolution of missions is much simplified.

The fact that German kings and rulers of Denmark or Poland viewed the expansion of their territories in the New Europe as the spread of Christianity should also be taken into consideration. The said rulers would authorise the expansion of Christianity and the

${ }^{14}$ It is worth mentioning the bull of Pope Innocent III to Albert the Bishop of Ikšksile (later Riga) sent on 19 April 1201 and quoted by M. Maccarrone, see. M. Maccarrone, 'I Papi e gli inizi della christianizzazione della Livonia', Gli inizi del Cristianesimo, p. 78: 'volens hec moderna tempora conformare prioribus et fidem catholicam propagare, predecessoribus vestris et vobis post eos puim ispiravit affectum ut, Livonensem ingressi provinciam, paganis evangelizaretis nomen Domini Iesu Christi, eorum sequentes exemplum quibus in evangelio legimus esse dictum: "Euntes docente omnes gentes baptizantes eos in nomine Patris et Filii et Spiritus sancti'. Cf. other examples - Fonnesberg-Schmidt, The Popes and the Baltic, pp. 114-5. The same was stated by Pope Alexander in his bull to Polish clergymen sent on 15 July 1256, see Vetera Monumenta Poloniae et Lithuaniae gentiumque finitimarum historiam iliustrantia, ed. A. Theiner, t. I (Osnabrück, 1969), p. 71: 'Verum quia gratuita debet esse conversio, non coacta, et ipse deus coacta servitia non acceptat' Cf. J. Muldoon, Popes, Lawyers and Infidels (Pennsylvania, 1979), pp. 11-12, 17, 30-1, 45-57.

${ }^{15}$ H.D. Kahl, 'Compellere intrare', pp. 374-8. 
missions. ${ }^{16}$ However, it is one thing to support a mission among your own subjects, and quite another to gain subjects by right of war. Hence in the first case we have social coercion employed by the ruler and an authorised missionary, whereas the second case is an instance of political coercion exercised by the ruler towards subdued peoples. Here the role of the missionary is different. The missionary undertakes yet another role when he becomes the enactor of political coercion as well. ${ }^{17}$ It is obvious that coercion in wartime and in peacetime was different. As further analysis suggests, there is a difference between those who carried out military operations and those who exercised coercion in peaceful missions.

Forms of social coercion in peaceful missions Before proceeding with an analysis of the topics of social and political coercion in Christian missions, it is necessary to briefly define the forms of coercion as presented in related sources. First of all, this refers to various types of threat that the ruler or the authorised missionary would employ to force the subjects to adopt Christianity. This embraces both psychological and physical coercion, which will be addressed further in the article. Other forms of coercion include the destruction of pagan artefacts, taking hostages, physical punishment for those who refused to adopt Christianity or even relatives, and various prohibitions (e.g. to eat meat on fast days, to work on holidays, etc).

Let us quickly scan through several of the most typical sources of the tenth to early 15 th centuries which reflect the abovementioned types of coercion in the Baltic region. The German chronicler

${ }^{16}$ E.g. the King of Sweden, Olaf, authorised St Ansgar's mission (Rimberto, Vita Anskarii, SRG, ed. G. Waitz [Hanover, 1884], §26, pp. 55-56: 'Qui regi Sueonum nomine Olef partis suae mandatum tale intimari iussit'), and the Slavic duke Gottschalk authorised the mission of John Scotus, the bishop of Mecklenburg (Helmoldi Presbyteri, Chronica Slavorum, Scriptores rerum Germanicarum (hereafter - SRG), ed. G.H. Pertz [Hanover, 1868], Lib. I, §22, pp. 49-50: '[...] est ad Godescalcum, apud quem commoratus, illis diebus multa milia paganorum baptizasse describitur'). A number of similar examples can be found. For the chronologically preceding sanctions and more information on the politics of missions in the Carolingian epoch, see R. Schneider, 'Karl der Große - politisches Sendugsbewußtein und Mission', Kirchengeschichte als Missionsgeschichte Bad. II: Die Kirche des Früheren Mittelalters, ed. E. Halbband, K. Schäferdiek (Munich, 1978), pp. 227-48.

${ }^{17}$ For more information, see M. Ščavinskas, 'Karinių/prievartinių misijų veiklos metodu problema baltų regione', Lietuvos istorijos metraštis. 2005 metai, 2 (Vilnius, 2006), pp. 5-28. 
Thietmar of Merseburg recorded that the Polish Duke Bolesław I the Brave (Bolesław I Chrobry) would not only knock out the teeth of those who disobeyed the prohibition to eat meat on fast days, ${ }^{18}$ but would publicly physically cripple those who indulged in sexual activities on holidays or during Advent or committed adultery. ${ }^{19}$ Another inscription by the same chronicler runs that St Stephen I (István I), the first Christian ruler of Hungary, would punish those who refused to be baptised or observe Christian traditions. ${ }^{20}$ Similar behaviour to that of St Stephen I is recorded in other sources as well. ${ }^{21}$ Being aware of Thietmar of Merseburg's negative attitude towards the Polish, and his unfavourable view of the Hungarians, one should not overestimate the abovementioned characterisation of Bolesław I the Brave and St Stephen I's behaviour. However, this also reveals the attempts these rulers made to consolidate Christianity among their subjects. In fact, it should be noted that in this case, Thietmar of Merseburg is a little too streamlined, as it remains unclear whether Bolesław I's strict requirements regarding the norms of Christian life were announced in the course of missions, but it is obvious that they were addressed to converts.

The sources concerning the last mission of St Bruno of Querfurt refer to the rigid actions of 'King' Netimer, directed against his brother who refused to be baptised: as Petrus Damiani has it, he was murdered. ${ }^{22}$ Similar forms of coercion were exercised by other

${ }^{18}$ Thietmari Merseburgensis episcopi Chronicon, ed. I.M. Lappenbergii (Hanover, 1889), Lib. IX (VIII), §2, p. 240: 'Et quicumque post LXII. carnem manducasse invenitur, abcisis dentibus graviter punitur.'

${ }^{19}$ Ibid.: 'Si quis in hoc alienis abuti uxoribus vel sic fornicari presumit, hanc vindictae subsequentis [poenam] protinus sentit. In pontem mercati is ductus per follem testiculi clavo affigitur et novacula prote Rosita hic moriendi sive de hiis absolvendi dura eleccio sibi datur.'

${ }^{20}$ Ibid., p. 241: 'regis Pannonici [the ruler of Hungary Waic-Stephen] [...] admodum crudelis et multos ob subitum furorem suum occidens. Qui cum christianus efficeretur, ad corroborandam hanc fidem contrta reluctantes subditos sevit et antiquum facinus zelo Dei exestuans abluit.'

${ }^{21}$ Annales Altahenses Maiores, SRG: Ex Monumentis Germaniae Historicis recudi fecit, ed. G.H. Pertz (Hanover, 1868), p. 17: 'Stephanus rex Ungaricus super avunculum suum Iulum regem cum exercitu venit, quem cum adprehendisset cum uxore ac duobus eius filiis, regnum vi ad christianismum compulit.'

22 Petrus Damiani, 'Vita beati Romualdi', Fonti per la Storia d'Italia, t. 94 (Rome, 1957), p. 56: 'Frater autem regis cum ipso pariter habitans, dum nollet credere, absente Bonifatio ab ipso rege peremptus est.' 
medieval rulers as well, for example, Duke Wartislaw of Pomerania. ${ }^{23}$ This is also revealed in sources relating to the Christianisation of Norway $^{24}$ (a number of similar examples can be found). Finally, it is worth mentioning the privilege for the nobility issued by the Grand Duke of Lithuania (and newly crowned King of Poland) Jogaila (Władysław II Jagiełło) and the letter from the Grand Duke of Lithuania Vytautas-Alexander. The ruler of Lithuania, Jogaila, ordered that 'omnes nacione Lithvanos utriusque sexus, cuiuscunque status, condicionis aut eminencie extiterint, in nostris dominiis [...] ad fide katholicam et sancte Romane Ecclesie obedienciam inducere, at(t) rahere, convocare ymo compellere in quacunque secta fuerint. ${ }^{25}$ This is followed with the enumeration of methods applied in the missions: appeal or subdue. Similar ideas are stated in Grand Duke Vytautas' letter of 1392 to the stewards of the GDL: '[...] ysz gdy ku wam przyyedzye xyadz byskup stym lystem y z moya pyeczaczya sam, tedy wy moy czywonowye sbyerzczye przed nym Lythwa, ktorzy szya nyekrczyly a thych okrczy byskup, yako yego wola.'26

Finally, these measures could have been undertaken by Mindaugas, the King of Lithuania, as well. Pope Alexander IV's bull sent to Mindaugas on 3 June 1255 dwells on the subjugation of pagans (and others) that find themselves at the 'dead-end of paganism', gaining them for the Christian faith. ${ }^{27}$

It was hardly only the Pope's intention (throughout almost the entire 13th century, the Holy See made every effort to bring the

${ }^{23}$ Ebonis, Vita S. Ottonis episcopi Babenbergensis, Pomniki dziejowe Polski (hereafter - PDP), ed. J. Wikarjak, seria II, t. VII, cz. 2 (Warsaw, 1969), Lib. III, $\S 6$, p. 105: 'Hus autem reverrendissimum dominum meum episcopum fama celeberrima ubique vulgatum, non sic tractare debetis nec potestis, quia missus est pape et dilectus domini nostri Lotharii regis invictissimi; nam et ipse Romani imperii princeps, et cuncti primates loco patris eum venerantes, consiliis eius abaudire per omnia satagunt. Unde sciatis procul dubio, quia si quicquam molestie aut controversie ei a vobis irrogari dominus rex audierit, sine mora cum exercitu superveniens, usque ad internocionem delebit vos et terram vestram.'

${ }^{24}$ D. Skre, 'Missionary Activity in Early Medieval Norway. Strategy, Organisation and the Course of Events', Scandinavian Journal of History, 23 (1998), pp. 10-11.

${ }^{25}$ Codex Diplomaticus Ecclesiae Cathedralis necnon dioeceseos Vilnensis (hereafter - $C D E$ ), no. 6, pp.13-14 (Jogaila's letter of 22 February 1387).

${ }^{26}$ Ibid., no. 23, p. 39 (Grand Duke of Lithuania Vytautas' letter to stewards of 1392).

${ }^{27}$ Mindaugo knyga. Istorijos šaltiniai apie Lietuvos karaliu, ed. D. Antanavičius, D. Baronas, A. Dubonis, R. Petrauskas (Vilnius, 2005), p. 78. 
Eastern Church back to the Lord's fold), or rather instructions that should be followed by the new Christian King Mindaugas. Most likely, Mindaugas realised the new possibilities that opened out in front of him following the adoption of Christianity, which had become one of the methods facilitating the enforcement of the king's will over his subjects and the legitimisation of his authority, upholding the famous view cuius regio, eius religio, which was actually first formulated only in the 17 th century. ${ }^{28}$ This is also suggested by the narrative part of the abovementioned bull (Pope Alexander IV mentions a letter received by Mindaugas).

The abovementioned facts shed light on the type of coercion implied when speaking about peaceful Christian missions. The Polish Duke Bolesław I the Brave, the King of Hungary St Stephen I, and other rulers, kings of Norway and other Scandinavian countries, and finally Mindaugas, Jogaila and Vytautas, made use of certain methods of coercion against their subjects, incorporated into Christian missions. Yet one point should be particularly accentuated: all these rulers were 'home-grown', not conquerors. They employed their authority and the abovementioned methods of coercion (and not necessarily only them) to consolidate Christianity in their dominions. As the missionaries sought to involve local rulers and/or the nobility in the organisation of missions, and the dissemination and consolidation of Christianity, they became not only prophets of Christianity but also facilitators of the consolidation of the local ruler's authority. Therefore, it was possible to exercise coercion (but not necessarily physical) against those who refused to obey the ruler and adopt Christianity.

It turned this way because a reluctance to adopt Christianity, from the point of view of medieval authorities, was considered disobedience to the ruler himself. Opposition to the ruler implied a breach of loyalty and all relations. This is true speaking of future converts. The ruler who adopted Christianity was still the same ru-

${ }^{28}$ This phrasing defining the Catholic and Protestant religious relations between the ruler and his subjects appeared after the Augsburg Settlement (1555) and anchored after the Peace of Westphalia (1648). Since the subjects of a pagan ruler had to convert to Christianity once their ruler adopted the new religion, the phrasing is used by specialists in medieval history, though in a different context, cf. P. Urbańczyk, 'The Politics of Conversion in North Central Europe', The Cross Goes North, Processes of Conversion in Northern Europe, ed. M. Carver (New York, 2003), p. 20. 
ler, as the adoption of the new religion did not cancel the duty of obedience and loyalty to the ruler ${ }^{29}$ (we leave aside here the topic of the legitimisation of authority through Christianisation, as this is a separate case $^{30}$ ). For example, in 1212, the Duke of Polotsk, negotiating with Albert, the Bishop of Riga, emphasised his wish to sustain the loyalty of his subjects, that is, to continue receiving their taxes and fees. ${ }^{31}$ In this case, taxes and fees are the expression of political subjection.

A different case was those who would backslide from the ruler and Christianity. The abovementioned R. Wenskus dwelled on the coercion employed against apostates. Those who disobeyed the ruler were called apostates. Yet it does not really matter that in not all cases did they relapse into paganism. All that matters is the fact that the ruler could subdue these people by means of coercion. Thus, an apostate had to be forced to obey the ruler's will and adopt his faith.

On the other hand, Christian rulers were responsible for the salvation of their subjects, as they considered themselves God's vicars on earth, ${ }^{32}$ and thus could not accept the fact that their subjects (even those acquired by means of conquest) were pagans or of any other confession. Naturally, this concept underwent a certain evolution, which has to be chronologised. In the 12th and 13th centuries, when the controversy regarding the investiture was resolved in favour of the Apostolic Throne, the emperor had to act with the sword that was

${ }^{29}$ On the Christianisation of Iceland and Norway, R.M. Karras, 'God and Man in Medieval Scandinavia, Writing and Gendering the Conversion', Varieties of Religious Conversion in the Middle Ages, ed. J. Muldoon (Gainesvill, 1997), pp. 102-5, 107, 109-10.

${ }^{30}$ For more on the new political and religious prospects that Christianity offered to the converted ruler, see P. Urbańczyk, Władza i polityka we wczesnym średniowieczu (Wrocław, 2008), pp. 158-202. Cf. O. Sundqvist, Freyr's offspring. Rulers and religion in ancient Svea society (Uppsala, 2000), pp. 282-317.

${ }^{31}$ Heinrichs Livländische Chronik, SRG, ed. L. Arbusow, A. Bauer (Hanover, 1955), Lib. III, cap. XVI, §2, p. 102: 'Rex interim de Plosceke mittens vocavit episcopum, diem prefigens et locum, ut ad presenciam ipsius aput Gercide de Lyvonibus quondam sibi tributaries responsurus veniat' It is followed by the chronicler's reproach to the Duke stating that he was more interested in taxes and fees than the conversion of the Livonians, ibid., p. 103: 'Est enim consuetudo regnum Ruthenorum, ut quamcunque gentem expugnaverint, non fidei christiane subicere, sed ad solvendum sibi tributum et pecuniam subiugare.'

32 J. Canning, A History of Medieval Political Thought 300-1450 (London-New York, 2005), pp. 22-135. 
handed by the Pope (with a few exceptions). Meanwhile, in other kingdoms, the concept of two swords underwent a slightly different evolution. This is especially true speaking about the newly converted rulers of the New Europe. The abovementioned Pope Alexander IV's bull to Mindaugas shows that in his kingdom Mindaugas and noone else was responsible for preaching the Gospel. It was he who, with the help of missionaries and other clergymen, had to take care of the dissemination of the Christian faith. The question is whether this approach was the concept of the official Church, other secular dignitaries, or Mindaugas himself as the newly converted king. It is also possible that the missionaries who evangelised Mindaugas could have sketched a portrait of an ideal Christian ruler for him, which might have increased his motivation to adopt Christianity. This is true speaking about Jogaila as well. He was the one who undertook the organisation of the baptism of his pagan subjects. Hence, on the one hand, the adoption of Christianity represented obedience to the ruler, but on the other hand, the ruler himself was concerned that his present and future subjects should accept the same faith, thus unifying and centralising the state and demonstrating his power.

Other forms of coercion in peaceful missions However, not all of the abovementioned forms of coercion were of a social character. Prohibitions such as eating meat on fast days and indulging in sexual activities, and the destruction of pagan traditions and artefacts, were a part of the so-called 'spiritual' (psychological) sphere, and thus the coercion exercised was of both a 'spiritual' (if we can put it this way) and a social character. It should be emphasised that alongside the rulers, missionaries were also involved in the destruction of idols and the consolidation of Christian ways of life. The destruction of pagan artefacts (idols, traditions) was an inseparable part of Christian missions, thus certain aspects of coercion could be observed in the Tatmission method as well. This is well illustrated in hagiographies dedicated to St Otto of Bamberg and St Bruno of Querfurt, in the Chronicle by Thietmar of Merseburg, Deeds of the Bishops of the Hamburg Church by Adam of Bremen, and other sources from the period in question, which describe the destruction of pagan artefacts. ${ }^{33}$

${ }^{33}$ For more typical examples, see Wiperti, 'Hystoria de praedicatione episcopi Brunonis cum suis capellanis in Pruscia, et martirio eorum', PDP (Warsaw, 1960), t. I, p. 229; Thietmari Merseburgensis episcopi Chronicon, Lib. VI, §25; 'Magistri Adam Bremensis', 'Gesta Hammaburgensis ecclesiae pontificum', SRG, 
In fact, here we face a number of problems, such as whether the pagan Polabian Slavs, Scandinavians and Balts had idols, and if so, what they were. It is also unclear whether the descriptions of the demolition of idols and even shrines that appear in the said hagiographies were not borrowed from earlier hagiographic and other sources. ${ }^{34}$ This is especially true speaking about the hagiographies of St Otto of Bamberg, where the apostle of Pomerania was depicted as the first disseminator of Christianity, as if there had been no traces of Christianity in Pomerania before him. ${ }^{35}$ In any case, it is obvious that the societies of Balts, Polabian Slavs and Scandinavians had certain religious images which cannot now be fully reconstructed due to the lack of information. Thus, we can suppose that abrenuntiatio diaboli was exercised as part of the missions. ${ }^{36}$ Depaganisation should not be perceived in a narrow sense as the demolition of idols and the extinction of altars. Depaganisation was also performed on the level of everyday life through the introduction of new Christian norms and ways of life. The emotions of the future converts, which were depicted picturesquely by the authors of hagiographies and chroniclers, best convey the sense of insecurity, astonishment, anger, tears and fear which accompanied the missionary's words, and the way pagans strived to preserve their faith. By the way, the psychological

ed. B. Schmeidler (Hanover-Leipzig, 1917), Lib. IV, §18, Lib. IV, §30; Povest' vremenykh let, D.S. Likhachev (St Petersburg, 1996), p. 52; Ebonis, 'Vita S. Ottonis episcopi Babenbergensis', Lib. III, §10; Herbordi, 'Dialogus de Vita S. Ottonis', PDP, ed. J. Wikarjak, K. Liman, Seria II, t. 7, cz. 3 (Warsaw, 1974), Lib. II, §31; Helmoldi Presbyteri, Chronica Slavorum, p. 214.

${ }^{34}$ The depiction of paganism in medieval sources and the possibility for their interpretation still seem an attractive object of research for a number of scholars. The following relatively new studies are worth mentioning: S. Rosik, Interpretacja chrześcijańska religi pogańskich Stowian w świetle kronik niemieckich XI-XII wieku (Thietmar, Adam z Bremy, Helmold) (Wrocław, 2000); L.P. Słupecki, 'Pagan Temple - Christian Church. The Problem of Old Norse Temples', Between Paganism and Christianity in the North, ed. L.P. Słupecki, J. Morawiec, (Rzeszów, 2009), pp. 29-40; A. Jakobsson, "'Er Saturnús er kallaðr en vér köllum Frey”". The Roman Spring of the Old Norse Gods', ibid., pp. 158-164.

${ }^{35}$ A number of literary sources are dedicated to the issue. The newest studies include: S. Rosik, 'Conversio gentis Pomeranorum. Legitymizacja pomorskich misji św. Ottona z Bambergu w przekazach z XII wieku', Kościoł w monarchiach Przemyślidów i Piastów, ed. J. Dobosz (Poznań, 2009), pp. 375-84.

${ }^{36}$ S. Rosik, 'The Pomeranian Mission of St. Otto of Bamberg. Remarks on the Doctrine and Practice of Christianisation', Castri Dominae Nostrae Litterae Annales, vol. I, p. 171. 
atmosphere is well rendered in one episode of the Christianisation of Lithuania. The Czech missionary Jerome of Prague, who started destroying pagan sacred places, caused a huge wave of discontent among the locals:

Prior itaque Hieronymus assumpta bipenni excellentem quandam arborem detrunancauit [...] Ventum erat ad medium nemoris, ubi quercum uetustissimam, et ante omnes arbores religione sacram, et quam potissime sedem esse putabant, percutere aliquandiu nullus preasumpsit. Postremo, ut est alter altero audacior, increpans quidam socios [...] et mox ad arborem adacto ferro adiuuante multitudine ingens onus cum magno fragore prostrauit, totumque nemus succidit. Erant in ea regione plures syluae pari religione sacrae, ad quas dum Hieronymus amputandas pergit, mulierum ingens numerus plorans atque eiuland, Vitoldum adit, sacrum lucum succisum quaeritur. ${ }^{37}$

As Jerome of Prague's methods for the dissemination of Christianity became too drastic, his services were refused. ${ }^{38}$ Hence, the abovementioned actions of depaganisation which cause psychological stress should also be attributed to psychological coercion. Psychologists distinguish more than one form of psychological coercion (through words, actions, even through the senses, such as hearing). The psychological persuasion employed in the Wortmission should also be considered a certain type of psychological coercion, in case it in a way and to an extent facilitated the enforcement of Christianity. The missionary's claims that various misfortunes would befall people unless they agreed to adopt Christianity are attributable to a certain form of persuasion, which made the audience at least prick up their ears.

Another important aspect is the special control employed to ensure the results of psychological influence. Christianisation focused on the control of time, diet, marital sexual life, etc. The control of time facilitated the implementation of a Christian perception of time, as well as its literal observance: holidays had to be dedicated to God rather than to work, and the farming cycle was closely related to the liturgical calendar. The control of diet was employed in order to teach converts to fast on certain days, and other ways of mortifying the flesh. The control of marital sexual life implied not only restrictions related to immorality or 'family planning policy' (in modern terms) but also the formation of a Christian family and its validation in

${ }^{37}$ Baltu religijos ir mitologijos šaltiniai (BRMŠ), ed. N. Vèlius, vol. I (Vilnius, 1996), pp. 591-2 (Aeneas Piccolomini, Cosmographia).

${ }^{38}$ Ibid., p. 592: 'Vitoldus [...] reuocatisque literis, quas praesidibus prouinciarum declarat, iubens parere Hieronymo, hominem ex prouincia decedere iussit.' 
the eyes of society (through the publishing of bans, the sacrament of matrimony, etc; in fact, this became especially explicit after the Fourth Council of the Lateran). ${ }^{39}$ The enumeration of forms of control can be continued, but it is already obvious that they were based on techniques of psychological influence (other types were also used). A number of sources suggest that the missionaries who catechised catechumens and continued to integrate converts into communities (future parishes) performed the control of the norms of life. The activities of St Otto of Bamberg are important to the Baltic region. For example, he insisted that the inhabitants of Pomerania observe all the norms of Christian life (abandon polygamy, observe holidays and fast days, restrain from debauchery, etc). ${ }^{40}$ Besides, one was expected to have only one wife, rather than several. ${ }^{41}$ Similar requirements imposed by missionaries are recorded in Helmold of Bosau's Slavic Chronicle, though he emphasises the burial of the dead in Christian burial-grounds ${ }^{42}$ (many more similar examples can be traced in the sources). Later, the abovementioned control would be validated by laws and resolutions passed by the synods of bishops. ${ }^{43}$ A typical example from Hungary belongs here. In 1092, Szabolcs church synod of the said kingdom resolved that if Jews who had adopted Christianity relapsed, they would be evicted from their homes until they reverted to the true faith. The same synod decided that Cuman and Jewish converts and others had to observe fast days and other requirements, and provided for punishment in cases of disobedience. ${ }^{44}$ Pope Nicholas III's legate Philip, who

${ }^{39}$ For more information on the abovementioned forms of control, see A. Sanmark, Power and Conversion. A Comparative Study of Christianization in Scandinavia (Uppsala, 2004), pp. 205-77.

${ }^{40}$ Ebonis, Vita S. Ottonis, Lib. II, §18, pp. 86-9.

${ }^{41}$ Herbordi, Dialogus, Lib. II, § 18, p. 95; Ebonis, Vita S. Ottonis, Lib. II, $\S 12$, p. 75.

${ }^{42}$ Ibid., Lib. I, §83, p. 168: 'Et precepit comes populo Sclavorum, ut transferrent mortuos suos tumulandos in atrio ecclesie, et ut convenirent in sollempnitatibus ad ecclesiam audire verbum Dei.'

${ }^{43}$ More information on this is available in one of the oldest rights of the Kingdom of Norway, see Sanmark, Power and Conversion, pp. 158-9, 214, 221-2, 238, 247.

${ }^{44}$ For more information, see N. Berend, At the Gate of Christendom. Jew, Muslims and "Pagans" in Medieval Hungary, c. 1000-1300 (Cambridge, 2001), pp. 211-2. 
visited Hungary in the second half of the 13th century, stated that the Cumans who failed to comply with the norms of Christian life had to face various punishments. ${ }^{45}$

Another technique of psychological influence is the perception of the past. Unfortunately, I cannot quote examples from the Christianisation of the Baltic societies in the tenth to the 13th centuries of how and in what way the reinterpretation of the past was manifested. However, interesting instances most likely illustrating attempts at the reinterpretation of the past can be traced in the sources related to the Christianisation of the Baltic region and research literature. The sources have it that the Danish King Harold purportedly 'baptised' the body of his dead father. ${ }^{46}$ A contrary action is described by Henry of Livonia, who claims that the Estonian apostates exhumed their dead from Christian cemeteries and buried them in accordance with pagan rites. ${ }^{47}$ Both cases illustrate the desire to turn back time, to change the past, to impose a new model of community upon one's ancestors, or, on the contrary, reinstate the previous one. After all, the christening of the dead body of a pagan is an apparent allusion to the transformation of the substance of the dead man's soul: it is given a chance to be saved. And on the contrary, cremation, in compliance with pagan traditions, of the bodies of converts who were buried in the Christian way was supposed to bring the souls of the dead back to their 'actual' being. In fact, the baptised Livonians who backslid from Christianity would plunge into the waters of the Daugava, believing that this would help them wash away the water of baptism and return to the 'primordial state'. ${ }^{48}$

In principle, the advocates of pagan tradition would also exercise psychological persuasion. Sources repeatedly reveal that the adoption of Christianity was threatened to be followed by natural or other disasters. The following example illustrates how pagan priests (and other people) threatened the Prussians during St Adalbert of

${ }^{45}$ Ibid., p. 221.

${ }^{46}$ Scholars still argue if the dead man was Harold's father or Harold himself, see M.H. Gelting, 'The Kingdom of Denmark', Christianization and the Rise of Christian Monarchy. Scandinavia, Central Europe and Rus c. 900-1200, ed. N. Berend, (Cambridge, 2007), p. 86.

${ }^{47}$ Heinrichs Livländische Chronik, Lib. III, cap. 26, §8, p. 191: 'Et receperunt uxores suas, tempore christianitatis dimissas, et corpora mortuorum suorum, in cemeteriis sepulta, de sepulchris effoderunt et more paganorum pristigo cremaverunt.'

${ }^{48}$ Heinrichs Livländische Chronik, Lib. II, §8, p. 11. 
Prague's mission: if the Prussians continued to listen to the Bishop of Prague, the soil would become poor, livestock would die, etc. ${ }^{49}$ It is worth mentioning the story recorded by Henry of Livonia about Theodoric, a Cistercian monk who later became the first bishop of Estonia. There were intentions to sacrifice him to the gods in order to get a good crop, etc. ${ }^{50}$ The abovementioned examples show the fact of the practice of psychological persuasion in the reasoning of both sides. The line between psychological persuasion and psychological coercion is so tenuous that at times it is almost impossible to indicate it. However, it is obvious that psychological persuasion played an important role in the missions.

\section{Coercion exercised by missionaries fulfilling secular functions}

The detection of the watershed between the work methods of a secular ruler and a missionary, in cases when the missionary fulfilled secular functions, also causes lots of complications. By the way, it is noteworthy. This was the case in Livonia and Prussia before the arrival of the Livonian Brothers of the Sword and the Teutonic Order. What the missionaries faced there were not political communities represented by a ruling family at the top of the nobility, but a scattered social elite crowned by more than ten rival families. But they competed in land ownership, the methods of slave disposal conditioning a more effective appropriation of value added from the tribal territory in their control, rather than in the attempts to politically consolidate the country. As the latest research suggests, the Prussian nobility was politically immature and polarised at the time when the first missionaries from Łekno monastery set off on their missions. ${ }^{51}$ Even though the first missionaries in Prussia, such as Christian, attempted to negotiate with individual noblemen, ${ }^{52}$ they were too weak to guarantee the support and necessary conditions for a successful mission. A slightly different situation was observed along the Daugava. It is believed that by the beginning of the 13th

${ }^{49} B R M \check{S}$, vol. I, p. 181.

${ }^{50}$ Heinrichs Livländische Chronik, Lib. I, §10, p. 4.

${ }^{51}$ W. Długokęcki, 'Prusy we wczesnym średniowieczu (IX-XIII wiek)', Bruno z Kwerfurtu. Osoba - dzieło - epoka, ed. M. Dygo, W. Fałkowski (Pułtusk, 2010), pp. 16-22, 49-56, 60-1.

${ }^{52}$ This is evident from the gifts that some of the Prussian noblemen gave to Bishop Christian, see Preußisches Urkundenbuch. Politische Abteilung (hereafter$P U B)$, Bd. I, no. 9-10, pp. 7-8. 
century, the rulers of Jersika and Koknese had achieved a certain level of political development. ${ }^{53}$ Undoubtedly, the Principality of Polotsk influenced the fact. Still another situation, yet in essence similar to the territorial structures along the Daugava, settled in the tribal society of the Polabian Slavs. In fact, the level of political development in the territories inhabited by the Polabian Slavs, was rather uneven. ${ }^{54}$ Still, and all in the course of the conquest of the Polabian Slavs, the Dukes of Saxony and Kings of Germany faced poorly politically organised tribes, where necessary decisions were made collegially by the nobility of the tribe and the so-called 'national' senate. ${ }^{55}$ The summit of the tribal senate was represented by elected military leaders. Due to the close proximity to Saxony and the political elite of the empire, the military leaders had already adopted certain principles of political leadership ${ }^{56}$ (the process probably started back in the times of the Carolings ${ }^{57}$ ). Evidently, the said principles were interlaced with Christianity and its ideas, ${ }^{58}$ giving a new sense to the nature of the leader's institution, which

${ }^{53}$ A. Šnē, 'Understanding Power: on the Study of Later Prehistoric Social and Political Structures in Latvia', Interarchaeologia, Vol 1: Culture and Material Culture, ed. V. Lang (Tartu-Riga-Vilnius, 2005), pp. 60-7; idem, 'The Emergence of Livonia: The Transformations of Social and Political Structures in the Territory of Latvia during the Twelfth and Thirteenth Centuries', The Clash of Cultures on the Medieval Baltic Frontier, ed. A.V. Murray (Burlington, 2009), pp. 58-64.

${ }^{54}$ For more information, see J. Strzelczyk, Stowianie połabscy (Poznań, 2002), pp. 13-19; C. Lübke, 'Forms of Political Organization of the Polabian Slavs (until the 10th century A.D.)', Origins of Central Europe, ed. P. Urbańczyk, (Warsaw, 1997), pp. 115-122. Cf. the same author 'Ests, Slavs and Saxons: Ethnic Groups and Political Structures', Maritime Culture of the North. Vol.2: Wulstans Voyage. The Baltic Sea Region in the Early Viking Ages as Seen from Shipboard, ed. A. Englert, A. Trakadas (Roskilde, 2009), pp. 50-5.

${ }^{55}$ For more information, see K. Modzelewski, Barbaru Europa (Vilnius, 2007), pp. 309-56.

${ }^{56} \mathrm{Cf}$. the example given by Helmold of Bosau depicting the marriage of the chief of the Obodrites to the sister of the bishop of Oldenburg (many more similar examples can be found), see Helmoldi Presbyteri, Chronica Slavorum, Lib. I, $\S 13$, p. 32.

${ }^{57}$ For more information, see I. Wood, The Merovingian Kingdoms 450-751, (London-New York, 1994), pp. 285-6.

${ }^{58}$ C. Lübke, 'Christianity and Paganism as Elements of Gentile Identities to the East of the Elbe and Saale Rivers', Franks, Northmen and Slavs: Identities and State Formation in Early Medieval Europe, ed. I.H. Garipzanov, P.J. Geary, P. Urbańczyk (Tournhout, 2008), pp. 193-202. Unsurpassed remains the study of H. Łowmiański, see H. Łowmiański, Religia stowian i jej upadek (w. VI-XII) (Warsaw, 1979). 
gradually developed into the institution of the ruler of the territory. Some researchers are apt to believe that part of the local elite of the Polabian Slavs had formed, or were in the process of forming, local territorial dynasties, which was related to the rise of the qualitatively new concept of power. ${ }^{59}$ Therefore, the local elite, which were in certain relations with the German nobility, were interested in the promotion of the missionaries. Here, the missionaries found pro-German representatives of the elite, who realised that their life at the helm of the territory became directly related to the principles accompanying the consolidation of German authority.

As has already been mentioned, the missionaries in Prussia and Livonia (and also in Finland) did not come across any noblemen who would have considered themselves vassals of the King of Germany or the Duke of Saxony. In Prussia, the most potential supporters of the missions could only have been the dukes of polarised Poland (we can observe their isolated initiatives ${ }^{60}$ ). In Livonia, the nearest political power was Polotsk and its duke, whom the first missionaries addressed regarding their missions. However, the ruler of Polotsk was a representative of the Eastern Church who had his own objectives regarding the territory along the Daugava; thus, as was the case with Prussia, the missionaries here had to take certain measures to safeguard the success of their missions. This required the formation of political organisations, which, as we can see, was finally accomplished. Prior to the establishment of the Livonian Brothers of the Sword near the Daugava, and the relocation of the Teutonic Order to the Vistula, missionaries authorised by the Holy See were in fact the only enactors of political power. Hence there were other forms of coercion employed in the missions. To be precise, the methods were the same, but filled with a different content. After all, the missionaries as the only enactors of political power were not viewed by the converts as their 'own' rulers, as were the abovementioned rulers of the New Europe. The converts regarded the members of the elite of the local tribal society, such as the nobleman Caupo of Turaida, as 'insiders', thus the missionaries sought to win them over in the first place. However, the

${ }^{59}$ Lübke, 'Forms of Political Organisation', pp. 120-1. Cf. Modzelewski, Barbaru Europa, pp. 308-72.

${ }^{60}$ For more information, see J. Powierski, Stosunki polsko-pruskie do $1230 \mathrm{r}$. Ze szczególnym uwzględnieniem roli Pomorza Gdańskiego (Toruń, 1968). 
particular circumstances (e.g. the promises of the missionaries to help the Livonians and Semigallians defend themselves against the assaults of the Lithuanians), and the formation and implementation of political structures, allowed the missionaries to monopolise the functions of the local ruler. This should be taken into consideration when differentiating forms of coercion in Christian missions.

Let us consider a few more typical examples from the activities of the first bishops of Livonia, Meinhard and Berthold, described concisely by the chronicler Henry of Livonia. It had already been noticed in historiography that the army was frequently at Meinhard's service (for instance, when the castle of Ikšksile was attacked, the Semigallians were resisted with the help of arrows), ${ }^{61}$ and as Henry the Livonian has it, Berthold came to Livonia accompanied by crusaders. ${ }^{62}$ Interestingly, the Livonians were aggrieved about the arrival of crusaders, and urged to preach the Gospels with the help of words rather than fists. ${ }^{63}$ Actually, Albert of Buxhoeveden, the third Bishop of Livonia, would take hostages from the Livonian nobility, ${ }^{64}$ even before the Livonian Brothers of the Sword were established in 1202 (ratified by the Pope in 1204), which can be considered as one of the forms of coercion. Thereby, in these cases, all forms of coercion were inspired by the missionaries themselves. Finally, the distribution of the first feudal tenures to crusaders, as performed by the same Bishop Albert, ${ }^{65}$ as well as the primary subordination of the Livonian Brothers of the Sword to the same bishop (who at the same time also served as a missionary), reveal that in the territories which had no political communities, or were still in the process of their formation, some missionaries would fulfil the function of the creation of the said community. Hence, the form of coercion exercised against future converts differed from that employed by the local ruler against his subjects.

${ }^{61}$ For more information, see Jensen, 'The Early Stage of Christianisation in Livonia', p. 209. However, it should be noted that the arrows were directed not against the Livonian converts but against the pagan Semigallian invaders who were not the object of Meinhard's mission of evangelisation, see Heinrichs, 'Livländische Chronik', Lib. I, §6, p. 3: 'Eo tempore Semigalii, pagani vicini [...] cum [...] putabant se stulta sua optinione castrum in Dunam trahere, sed a balistariis vulnerati dampna reportantes abierunt.'

${ }^{62}$ Heinrichs Livländische Chronik, Lib. II, §3, p. 9: 'signum crucis accipientibus et contra perfidos Lyvones se armantibus remissionem indulget peccatorum.'

${ }^{63}$ Ibid., Lib. II, §4, p. 10: '[...] eos, qui fidem susceperunt, ad eam servandam compellas, alios ad suscipiendam eam verbis non verberibus allicias.'

${ }^{64}$ Ibid., Lib. III, cap. I, §4, p. 14.

${ }^{65}$ For an example, see ibid., Lib. III, §1, pp. 15-16. 
Political coercion and the role of the missionaries Following the formation of the Livonian Brothers of the Sword and the relocation of the Teutonic Order to Prussia, coercion against the subdued nations was enacted by the knights of the abovementioned orders rather than missionaries or monks, thus the role of the missionaries in acts of political coercion changed. This is especially true speaking about the Teutonic Order, as both universal powers, the Holy See and the Emperor, granted it indisputable rights to the conquered territories, and made it immune from the authority of the local bishop. ${ }^{66}$ Political coercion first of all provided for a political rather than any other possibility to subdue the converts. Thus, all forms of coercion exercised in missions on conquered territories differ in their content from those enacted by the local ruler. The missionaries would become the instruments of the said political subjugation, and in this case their relation with coercion was ambivalent:

1) On the one hand, the missionaries as instruments of political subjugation were part of this subjugating action, thus their missions acquired an obvious political undertone (the conquest was followed by separate, most likely demonstrative, cases of baptism, signifying the finalisation of political subjugation). For example, in 1219, when part of the Estonian territories was devastated, their inhabitants started pleading for mercy and peace, agreeing to be christened and to submit to the German authorities by allowing them to take hostages. ${ }^{67}$

${ }^{66}$ A huge historiography is dedicated to the analysis of these rights. It is worth mentioning H. Boockmann, Der Deutsche Orden. For more information on the Golden Bull of Rimini, see T. Jasiński, 'Złota Bulla Fryderyka II dla zakonu krzyźackiego z roku rzekomo 1226', Roczniki Historyczne 60 (1994), pp. 107-54.

${ }^{67}$ Heinrichs Livländische Chronik, Lib. III, cap. XXIII, §7, pp. 160-1: 'Et postquam graviter nimis diebus quinque totam terram illam percusserunt et milia multa populorum interfecerunt, venerunt tandem ad nos seniores provinciarum ... suppliciter pro pace petentes. Et ait Rodolfus, fratrum milicie magister: "Si ergo volueritis baptizari et eundem Deum unum christianorum nobiscum colere, pacem illam ... Et placuit eis verbum et statim promiserunt omnia christianitatis iura cum baptismo Rigensium se fideliter accepturos.' A typical remark by Henry of Livonia assessing the conquest of the Livonians and the baptism that followed, ibid., Lib. III, p. 43: 'Et merito post bella doctrina sequitur theologica, cum eodum tempore post bella omnia predicta conversa et baptizata sit tota Lyvonia' (the baptism was organised after the noble Livonian boys were taken hostage, ibid., Lib. III, p. 44: 'Prepositus itaque Rigensis iuxta verbum archiepiscopi acceptis obsidibus meliorum pueris de tota Lyvonia sacerdotes mittit ad predicationem'). 
2) On the other hand, elements of social coercion could also have been observed in the missions. They were most obvious in the attempts to burden the conquered converts with various fees and church taxes, thus leading to their relapse to paganism. ${ }^{68}$ In order to prevent this, the conquerors were urged to restrain from burdening the converts with new obligations ${ }^{69}$ (for example, the Livonians asked their bishops to reduce the tithes ${ }^{70}$ ). However, it was strictly demanded that the converts observe all rules of Christian life, as is illustrated by the renowned Treaty of Christburg with the Prussian nobility. The treaty provided that the Prussians should abandon the cremation of their dead, and bury them in churchyards instead, stop listening to their pagan priests, have only one wife, etc. Finally, the Prussians agreed to attend church on holidays, pay tithes and support the Church. ${ }^{71}$ A little earlier, a similar peace treaty, which also provided for the observance of Christian norms, was made with the nobility of the island of Saaremaa. ${ }^{72}$ Later, legal matters were settled in special statute-books received by Prussia and Livonia. Those who failed to comply with their provisions were punished accordingly. ${ }^{73}$

${ }^{68}$ Helmoldi presbyteri Bozoviensis, Cronica Slavorum, Lib. I, §16, p. 39: ‘quod idem dux [Duke Bernard II of Saxony tam paternae quam avitae devocionis, quam erga Slavos habebent, penitus inmemor, gentem Winulorum per avariciam crudeliter opprimens ad necessitatem paganismi coegit.'

${ }^{69}$ Liv-, Esth- und Curländisches Urkundenbuch nebst Regesten (hereafter $L U B$ ), ed. F.G. Bunge (Reval, 1853), 1, no. 28, pp. 35-6. This problem can also be viewed from another angle - the tithe is a type of feudal taxation which means that feudalism, with all its consequences, including the payment of tithes to the Church, was imposed on converts, which was completely new to the territories inhabited by the West Slavs and Balts. St Otto of Bamberg also invited not to abuse the converts. Cf. Ebonis, Vita S. Ottonis e Lib. III, §6, p. 106: 'Sed pars sanioris consilii affirmabat infinite imis esse insipientie, cum circumiacentium nationum provincie, totusque Romanus orbis christiane fidei ingum subierit, se velut abortivos, gremio sancte matris ecclesie abalienari.'

${ }^{70}$ Heinrichs, Livländische Chronik, Lib. III, cap. XV, §5, pp. 92-3: 'Lyvones ... supplicantes episcopis et petentes iura christianorum et maxime sibi alleviari.'

${ }^{71} B R M S$, vol. I, pp. 238-41 (Treaty of Christburg).

${ }^{72}$ LUB, 1, pp. 220-1: 'Multis itaque placitis et interlocutoriis hinc inde habitis, praedicti apostatae in hoc tandem universaliter et finaliter conveniunt: Quod si ecclesia subscriptam formam sine omni permutatione violenta in perpetuum ab ipsis acceptare dignaretur, vellent redire devoto animo et prompta voluntate ad catholicae fidei, a qua diabolico instinctu recesserant, unitatem.'

${ }^{73}$ V.T. Pashuto, Pomezania. 'Pomezanskaia pravda' kak istoricheskii istochnik izuchenia obshestvennogo i politicheskogo stroia Pomezanii XIII-XIV vv. (Moscow, 1955); E.L. Nazarova, “'Livonskie pravdy' kak istoricheskii istochnik', Drevneishie gosudarstva na territorii SSSR, Materialy i issledovania, 1979 god (Moscow, 1980), pp. 5-219. 
Actually, these requirements were declared when the missions were still in progress, and it was not exactly clear whether it would be the missionary or somebody else who would take the initiative for political subjugation into his hands. For instance, in 1216 the Pope (probably Honorius III) issued a bull which demanded that the Prussian converts observe the following rules of Christian life: to have no more than one wife, acquired not by means of ransom, to restrain from debauchery, and to honestly pay tithes. ${ }^{74}$

In fact, there is little evidence of acts of the destruction of pagan artefacts in the territories inhabited by the Balts (the Treaty of Christburg mentions one idol named Curche). However, if such actions took place, it is obvious that one form of coercion was employed when the destruction was authorised by the local ruler who had adopted Christianity or had no objections to the dissemination of the new religion, and quite another when the destruction of idols was initiated by the conqueror, and the local elite were mere mute observers who had lost their former power.

Hence the coercion exercised by the conqueror was not equivalent to the coercion employed by the local leader against his subjects. Thus, political coercion bred rather different relations between the conqueror and the local community. Therefore, the coercion exercised by the conquerors in the course of the authorised missions differed in its essence. Having stated this, the question whether Schwertmission was political or social coercion remains open.

The conqueror first of all had to subdue the pagans and then proceed with Christianisation. This type of conqueror would normally face pagans rather than apostates. Were these conquests part of the Christian missions? If not, why then do we attribute Schwertmission to conquests and Crusades? After all, the Crusade (as well as the tricky to explain and translate hybrid term Missionskrieg) was a form of conquest of territories!

An attempt at generalisation The remarks presented above demonstrate how difficult it is to define the coercion employed in Christian missions. However, this definition is necessary, in order to be able to analyse the essence of Schwertmission. One thing is obvious: Schwertmission were neither conquests carried out by the Teutonic

${ }^{74}$ PUB, Bd. I, no. 13, pp. 9-10. 
Order and its branch along the Daugava ${ }^{75}$ nor Crusades, which were one of the forms of conquest. But Schwertmission cannot be political coercion either, as its enforcement required the subjugation of the disobedient. As the conquerors exercised political (military) coercion against the conquered, Schwertmission defines the remaining two forms of coercion - social and psychological.

Hence, Schwertmission were a form of social and psychological coercion employed in the so-called peaceful Christian missions by missionaries who were granted the support of the local rulers. This type of coercion could be exercised with the help of both swords and words. Besides, it has become obvious that coercive elements were also present in the methods of Wortmission and Tatmission. It should be noted that this was not military coercion; in other words, there was no 'sword evangelisation' whatsoever. But what about the missionaries who took over the functions of the constitutors of political structures and employed coercion in their missions? As the examples presented above suggest, the coercion exercised by the missionaries can also be attributed to Schwertmission. When the military operations that led to the establishment of new political structures were launched along the Daugava and in Prussia, we already had to deal with military coercion. This military or political coercion differed from the one employed in Christian missions. It was also different from the coercion exercised by the missionaries who had taken over the functions of the constitutors of political structures.

However, this definition of Schwertmission leads to a paradox: psychological methods in this case are equated to the sword, as the term is coined from two words, 'sword' and 'mission'. Here comes the question whether this term should be used at all. However, this is already a topic for further discussion. For the meantime, we can do nothing but continue using this term, which is well established in historiography ...

Thus, it can be stated that elements of coercion were present in the so-called peaceful Christian missions, but it was not military or political coercion as exercised by the conqueror, the Teutonic Order in Prussia and the Livonian Brothers of the Sword along the Daugava.

75 Ščavinskas, 'Karinių/prievartinių misijų veiklos', p. 26. 
Author Details

Dr Marius Ščavinskas is a postdoctoral researcher at the Department of the History of the Grand Duchy of Lithuania at the Lithuanian Institute of History. Major academic interests include the topics of Christianisation and Europeanisation of the Baltic tribes and the Lithuanian state and Crusades to the Baltic region.

Address: Lithuanian Institute of History, Kražių 5, LT-01108 Vilnius

E-mail: marius_scavinskas@yahoo.com

\title{
PRIEVARTOS FORMOS TAIKIOSE KRIKŠČIONIŠKOSE MISIJOSE
}

\author{
Santrauka
}

\section{MARIUS ŠČAVINSKAS}

Šiame straipsnyje analizuojamos prievartos formos, taikytos taikiose krikščioniškose misijose. Prievartos formos, naudotos krikščioniškose misijose, buvo įvairios: pradedant vykdyta depagonizacija (stabų griovimu), grasinant ar net smurtiškai susidorojant, baigiant psichologinèmis ịtaigos formomis. Atlikus tyrimą aiškejja, kad prievartą galime skirstyti i dvi pagrindines dalis - socialinę ir politinę. Pagal vykdomų misijų darbo formas dar nuo $\mathrm{XX}$ a. pirmos pusès yra prigijęs misijų skirstymas į tris dalis - Wortmission (misijos žodžiu), Tatmission (misijos veiksmu) ir Schwertmission (misijos kalaviju). Socialinę prievartą savo pavaldinių atžvilgiu vykdė „savas" valdovas, taigi, ne užkariautojas. Tokie valdovai buvo Lenkijos kunigaikštis Boleslovas Narsusis, Vengrijos karalius šv. Steponas ir daugelis kitų. Tokie valdovai buvo ir Mindaugas, Jogaila bei Vytautas. Politinę prievartą vykdė užkariautojas, koks prūsams buvo Vokiečių ordinas, arba Dauguvos visuomenėms Kalavijuočių ordinas (vèliau tapęs Vokiečiu ordino dalimi). Dèl šios priežasties savo esme socialinė prievarta skyrèsi nuo politinès prievartos.

Skyrèsi ir misionierių vaidmuo vykdant socialinę bei politinę prievartą. Vienas reikalas, kai misionieriai tapdavo socialinès prievartos reiškejjais, visai kas kita, kai - politinès. Tačiau tarpinejje būsenoje buvo tie misionieriai, kurie èmèsi igyvendinti politinių struktūrų organizavimą, nesant šioms struktūroms. Tokie misionieriai naudojo tam tikras prievartos formas (ginklus, èmé ikaitus ir pan.), nors konvertitams nebuvo nei „savas“ valdovas, nei užkariautojas, koks buvo Vokiečiu ordinas. I tai atsižvelgus darytina išvada, kad Schwertmission galèjo būti socialine prievarta, tačiau ne politinè. Tad savo esme Schwertmission negalime prilyginti Kryžiaus karams, kaip neretai daroma istoriografijoje. 